\title{
The Research on Business English Teaching in the Era of Big Data
}

\author{
Huatian Liu \\ Changchun Normal University, Changchun 130032, China.
}

\begin{abstract}
In people's daily work and life, almost every aspect relates to the data. With the advent of the era of big data, the big data provides conditions for our working and learning, and also promotes the reform and innovation of education at the same time. The Business English is an international professional subject. And the era of big data sets a scientific and progressive stage for it, and builds a good environment and space for professional training of Business English. The paper introduces the influence of the era of big data on Business English teaching, and discusses the optimal teaching strategy for Business English further to provide some referential advice.
\end{abstract}

Keywords: The era of big data; business English; teaching research.

\section{Introduction}

With the development and the advance of the technology, the internet has been widely used, and the development of human civilization has entered the era of big data, which has exerted a great influence on business English teaching. With the growth of the economic globalization, the business English teaching has catched the scholars' attention. The business English teaching in the age of the big data is faced with a full reform and innovation, and in the course of teaching, we need to incorporate the need for social development, and to discuss the efficient teaching mode to promote the stable and further development of business English, and to provide more and more comprehensive quality business English professionals for the society.

\section{The Influence of Big Data Era on Business English Teaching}

\subsection{Impact on Teaching Resources}

In traditional business English teaching, teachers usually teach detailed explanation in class according to the knowledge in textbooks, which is limited in teaching space and teaching time. However, in the era of big data this situation relying too much textbooks teaching has been changed. Through the internet we can find plenty of teaching resources, and teachers can combine the resources with teaching content to make practical teaching courseware, in order to improve business English teaching efficiency. In addition, the powerful search engine on the Internet not only provides abundant teaching resources for business English, but also sets up a bridge for communication, which can broaden students' horizon, enhance students' interest in learning English, provide students with new learning ideas, let students master English learning skills quickly, and improve their application ability of business English.

\subsection{Impact on Teaching Methods}

In the era of big data, various teaching methods can be provided for business English through corpus and search engine on the internet. Business English translation teaching is usually difficult in the teaching, and many students think that English translation is a kind of language in learning forms but ignoring the content. But in the era of big data, teachers can guide students to search the relevant knowledge of vocabulary and grammar through the internet, and adopt various teaching methods to reduce the burden of teaching, the difficulty for the students to learn business English translation, and then catch students' interests of learning. 


\section{Business English Teaching Optimization Strategy in Big Data Era}

\subsection{Create a Modern Teaching Class}

In the teaching of business English in the large data era, the computer multimedia teaching is used to combine with the listening, speaking, reading, writing, and translate the traditional English teaching into a modern business English teaching class. In business English teaching, the teachers' courseware should combine with the teaching material content and the key points in the textbook, through the computer software to put the knowledge into simple courseware, at the same time, pay attention to the rationality of the design of courseware sound, image to show students vivid image and teaching content. What's more, the appropriate interaction questions can increase the interactivity between teachers and students, which lets the students in relaxing atmosphere master business English learning skills.

\subsection{Establishing an Informational Teaching System}

The establishment of an information-based teaching system is an important measure of business English teaching in the era of big data. The Internet and the computer can not only offer abundant learning resources for teachers and students, also build platform for communication between teachers and students, in which teaching resources can be updated and different electronic communication channels can be provided, such as a network communication station, group discussion space or email etc. In the era of big data, a large number of teaching resources are provided for business English teaching. As a teacher, on the premise of improving students' English learning ability, the strong integration ability of big data should be scientifically utilized by teachers to set up an informationbased teaching system.

\subsection{Build a Scientific Teaching Design}

The Internet provides a lot of dynamic knowledge for learning business English, but without scientific and reasonable guidance, students will lose their orientation and deviate from teaching objectives in the vast amount of information resources. Therefore, which requires teachers to combine with traditional classroom teaching methods, give play to the role of timely guidance, inspiration and supervision, to build a scientific teaching design, in order to use the knowledge resources of big data well. First of all, teachers choose teaching examples as the breakthrough point, establish teaching tasks and key points, and guide students to learn relevant theoretical knowledge within a large framework. Second, according to the contents of the class teachers assign tasks. After class, students search and learn about the business English knowledge through the internet, and hand in their homework in school or professional BBS network platform, thus everybody can see each other's task. At the same time, in this way there are more competitions and communications between students, which also conforms to the contemporary students' learning characteristics.

To sum up, the era of big data business English teaching should be combined with the need for social development, change from teaching concept, and build a perfect business English network teaching system. By using the network teaching resources in the Internet, and break the limitation of space and time of the traditional teaching, then adopt diversified teaching mode, enhance the practicability of business English teaching continuously to promote the application ability of business English. In a word, the era of big data has provided abundant teaching resources and development opportunities for business English teaching, which requires teachers to master more modern information technology, explore new business English teaching fields constantly, and cultivate talents of business English.

\section{References}

[1]. Zhu Nan. "Internet + Education" in Practical Colleges of Applied English Personnel in the Cultivation of Practical Analysis [J]. English Square, 2015 (08). 
[2]. Ye Xingu. Innovation in English Teaching Under the New Normal[J]. Contemporary Foreign Languages Studies, 2015(12). 